This article was downloaded by: [Isfahan University of Technology]

On: 23 October 2010

Access details: Access Details: [subscription number 926807820]

Publisher Taylor \& Francis

Informa Ltd Registered in England and Wales Registered Number: 1072954 Registered office: Mortimer House, 3741 Mortimer Street, London W1T 3JH, UK

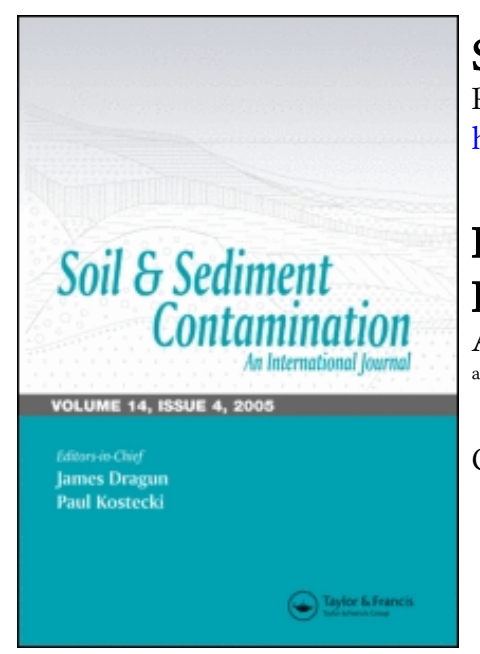

Soil and Sediment Contamination: An International Journal

Publication details, including instructions for authors and subscription information:

http://www.informaworld.com/smpp/title content=t713401148

\title{
Reclamation of a Petroleum-Contaminated Calcareous Soil Using
} Phytostimulation

Ali A. Besalatpour ; ; Mohamad A. Hajabbasia; Amir H. Khoshgoftarmanesh ${ }^{\mathrm{a}}$

a Department of Soil Sciences, College of Agriculture, Isfahan University of Technology, Isfahan, Iran

Online publication date: 10 September 2010

To cite this Article Besalatpour, Ali A., Hajabbasi, Mohamad A. and Khoshgoftarmanesh, Amir H.(2010) 'Reclamation of a Petroleum-Contaminated Calcareous Soil Using Phytostimulation', Soil and Sediment Contamination: An International Journal, 19: 5, $547-559$

To link to this Article: DOI: $10.1080 / 15320383.2010 .499920$

URL: http://dx.doi.org/10.1080/15320383.2010.499920

\section{PLEASE SCROLL DOWN FOR ARTICLE}

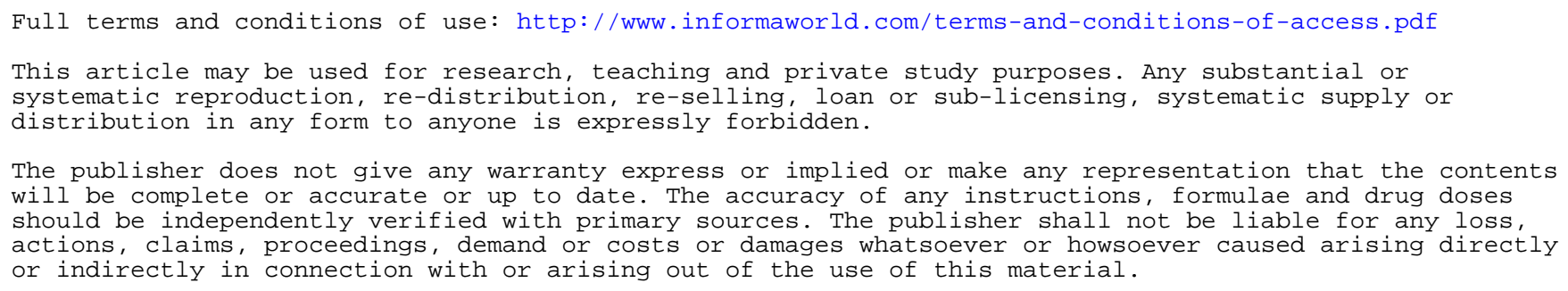




\title{
Reclamation of a Petroleum-Contaminated Calcareous Soil Using Phytostimulation
}

\author{
ALI A. BESALATPOUR, MOHAMAD A. HAJABBASI, \\ AND AMIR H. KHOSHGOFTARMANESH \\ Department of Soil Sciences, College of Agriculture, Isfahan University \\ of Technology, Isfahan, Iran
}

\begin{abstract}
Soil contamination by hydrocarbons poses a threat to groundwater and food chains. Hence, the elimination of these compounds from contaminated soil is vital. In this study, we investigated the degradation of total petroleum hydrocarbons (TPHs) in the rhizosphere of tall fescue (Festuca arundinacea L.), agropyron (Agropyron smithii L.), safflower (Carthamus tinctorius $L$.), and sunflower (Helianthus annus $L$.) at three soil contamination levels, denoted as $C_{0}\left(<50 \mathrm{mg} \mathrm{kg}^{-1} \mathrm{TPH}\right), C_{I}\left(40360 \mathrm{mg} \mathrm{kg}^{-1} \mathrm{TPH}\right)$, and $\mathrm{C}_{2}\left(69760 \mathrm{mg} \mathrm{kg}^{-1} \mathrm{TPH}\right)$. The dry matter yield decreased with increasing contamination level in all four plant species. Safflower seedlings grew poorly and died within 10 to 11 weeks at the highest contamination level. Soil microbial respiration rate increased by 77 and $80 \%$ in the rhizosphere soil of tall fescue and agropyron, respectively, in the $C_{1}$ treatment as compared to the control. The TPH concentration decreased by 71 and $69 \%$ in the $C_{1}$ treatment and by 45 and $42 \%$ in the $C_{2}$ treatment in the rhizosphere soil of agropyron and tall fescue, respectively. Sunflower had no significant effect on the degradation of the contaminating petroleum hydrocarbons in comparison to plant-free control. According to these results, agropyron and tall fescue appear to be suitable choices for the phytoremediation of investigated petroleum-contaminated soils.
\end{abstract}

Keywords petroleum hydrocarbons, phytoremediation, soil contaminations, soil microbial respiration

\section{Introduction}

Petroleum hydrocarbons are among the most common toxic organic contaminants in the environment (Huang et al., 2005). Soil contamination by petroleum hydrocarbons was found to result from petroleum extraction, refining, transportation, accidents, consumption and leakage of tanks, and pipeline ruptures (McNicoll and Baweja, 1995; Nicolotti and Eglis, 1998; Mol, 1999). Petroleum hydrocarbons in soil may be toxic to humans getting in contact with such soil, plants, and soil microorganisms, and also pose a risk of groundwater contamination (Siddiqui and Adams, 2001; Besalatpour et al., 2008). Therefore, there is an urgent need to find effective and low-cost technologies to clean up petroleum-contaminated soils (Palmroth et al., 2002). Physical, chemical, and biological methods can all be used for the remediation of such contaminated sites, but phytoremediation (removal of soil

Address correspondence to Dr. Ali A. Besalatpour, Department of Soil Sciences, College of Agriculture, Isfahan University of Technology, Isfahan 84156, Iran. E-mail: a_besalatpour@ag.iut.ac.ir 
contaminants via plants) has long been recognized as a cost-effective method for removal of contaminating petroleum hydrocarbons from soil, in particular approaches involving phytostimulation, i.e. rhizosphere degradation or plant-assisted bioremediation (Leyval and Binet, 1998; Joner and Leyval, 2001; Miya and Firestone, 2001). Phytostimulation is defined as the degradation of petroleum hydrocarbons through the stimulation of microorganisms in the rhizosphere; for example, by releasing exudates that intensify the activity of petroleumdegrading microorganisms (Nedunuri et al., 2000; Alkorta and Garbish, 2001; Newman and Reynolds, 2004; Kechavarzi et al., 2007).

For phytoremediation to become an effective method for the removal of petroleum contaminants, many restrictions and problems must be overcome (Rock, 1997; US. EPA., 2000). One serious limitation is that many plants are sensitive to the presence of petroleum hydrocarbons in soil. Such plants grow slowly and do not produce sufficient biomass (especially roots) in heavily contaminated soils for effective remediation (Huang et al., 2004). Thus, to achieve a maximum reduction in total petroleum hydrocarbon (TPH) concentration and to successfully establish a stable vegetation cover, plants should be chosen carefully so that they provide a maximum root surface area, are tolerant to the contaminants, and preferably are native to the area (Aprill and Sims, 1990; Smith et al., 2006). Native plants are often better in terms of survival, growth, and reproduction under environmental stress than plants introduced from another environment (Yoon et al., 2006). Previous research has shown that petroleum hydrocarbon degradation was enhanced in the rhizosphere soil of plants with healthy and extensive root systems. Large healthy plants often develop extensive root systems that are capable of pumping more nutrients through the soil system and providing increased surface area for TPH-degrading microorganisms (Hutchinson et al., 2001).

Many laboratory and pot experiments have demonstrated that plants can enhance the degradation of TPHs (Joner and Leyval, 2001; Palmroth et al., 2002; Huang et al., 2005; $\mathrm{Xu}$ et al., 2006). For instance, Liste and Felengtreu (2005) reported that after 95 days the final TPH concentrations in the soil planted with white mustard (Sinapsis alba L.) and summer vetch (Vicia sativa L.) were 15.6 and 12\% lower than unplanted soil. Chaineau et al. (2000) observed that the degradation of polycyclic aromatic hydrocarbons (PAHs) was faster in the presence of maize (Zea mays L.) than in unplanted control soil. Radwan et al. (2000) found a $46 \%$ reduction of crude oil in 12 weeks with broad bean (Vicia faba L.) as compared to a $33 \%$ reduction with no plants.

Little information is available on the potential of phytoremediation on petroleumcontaminated soils in arid and semi-arid regions. Apart from the climatic conditions, soil properties are generally quite different from those of more humid regions. For example, the soils of arid regions are often calcareous, salt-affected, and low in biological activity. These conditions may have an important influence on the rate and extent of petroleum hydrocarbon degradation in contaminated soils. In Iran, soil pollution by petroleum products is widespread, particularly around oil refineries, and a problem of increasing political concern. After various physical, chemical, and biological approaches to remediate large quantity contaminated soils have failed or were not cost-effective (Besalatpour et al., 2008), the objective of this study was to evaluate the capability of phytoremediation to eliminate petroleum compounds from petroleum-contaminated calcareous soil. Apart from two native grasses, we investigated the potential use of two common Iranian crop plants, sunflower and safflower, for this purpose. In addition to the reduction of soil TPH concentrations by the applied treatments, we determined the plant yield as an indicator of phytotoxicity effects and soil respiration rates as an indicator of a potential phytostimulation effect on soil microbial activity. 


\section{Materials and Methods}

\section{Soil Preparation and Properties}

Uncontaminated and petroleum-contaminated soils $(0-40 \mathrm{~cm}$ depth) were collected from farmland and oily waste landfills around the Tehran Oil Refinery Complex ( $35^{\circ} 30^{\prime} \mathrm{N}, 51^{\circ}$ $26^{\prime} \mathrm{E}$ ), respectively. The soils were air-dried and passed through a 4-mm sieve. Three different contamination levels were established by mixing contaminated and uncontaminated soil at different weight ratios. The contamination levels are denoted as $\mathrm{C}_{0}$ (uncontaminated soil), $\mathrm{C}_{1}\left(1: 1 \mathrm{w} / \mathrm{w}\right.$, uncontaminated: contaminated soil), and $\mathrm{C}_{2}(1: 3 \mathrm{w} / \mathrm{w}$, uncontaminated: contaminated soil). To ensure a homogenous distribution of the petroleum pollutants in the mixed soils, the soil samples were landfarmed in an open field for 21 days. The landfarming included irrigation (near the 0.7 field capacity) and aerating the contaminated soils every 3 days by hand using a garden hoe.

After the landfarming treatment, a total of approximately $1 \mathrm{~kg}$ soil was collected for each of the three contamination levels, passed through a 2-mm sieve and used for chemical and physical analysis. Soil $\mathrm{pH}$ was measured using a digital $\mathrm{pH}$-meter (Model 691, Metrohm AG, Herisau, Switzerland) (Thomas, 1996) and saturated electrical conductivity (ECe) using an EC-meter (Rhoades, 1996). The soil organic matter content was determined using the Walkley-Black method (Nelson and Sommers, 1982). Available phosphorus was extracted from the soil with $0.5 \mathrm{M} \mathrm{NaHCO}_{3}$ (Olsen and Sommers, 1982). DTPA-extractable metals $(\mathrm{Zn}, \mathrm{Fe}, \mathrm{Mn}, \mathrm{Cd}, \mathrm{Ni}$, and $\mathrm{Cu}$ ) were determined using the method of Lindsay and Norvell (1978). Total $\mathrm{N}$ was determined by the micro-Kjeldahl method (Bremner and Mulvaney, 1982).

\section{Soil TPH Concentration Analysis}

Total petroleum hydrocarbons were extracted from soil sample aliquots of $10 \mathrm{~g}$ each by means of a 24-hour Soxhlet extraction using a 1:1 (v/v) dichloromethane and n-hexane $(150 \mathrm{ml})$ mixture (Christopher et al., 1988). The TPH concentrations were determined in the extracts by means of gas-chromatography (GC) using a Delsi DI 200 chromatograph equipped with a direct injection port and a FID detector at $340^{\circ} \mathrm{C}$. The carrier gas was helium under $0.08 \mathrm{MPa}$, and the column was a CP Sil $5 \mathrm{CB}$ (Chrompack) capillary column (50 m by $0.32 \mathrm{~mm}$, film thickness $0.25 \mu \mathrm{m}$ ). The temperature was increased from 100 to $320^{\circ} \mathrm{C}$ at a rate of $3^{\circ} \mathrm{C} \mathrm{min}^{-1}$.

\section{Phytoremediation Experiments}

Based on a previous study on the growth of various plants on the petroleum-contaminated soil (Besalatpour et al., 2008), the following four plant species were selected for the phytoremediation trials: tall fescue (Festuca arundinacea L.), agropyron (Agropyron smithii L.), safflower (Carthamus tinctorius L.), and sunflower (Helianthus annus L.). Seeds were planted at 1 to $2 \mathrm{~cm}$ depth in plastic pots having $150 \mathrm{~mm}$ diameter and $250 \mathrm{~mm}$ height with about $3 \mathrm{~kg}$ soil in four replicates. A disc of filter paper was placed at the bottom of each pot to prevent soil loss through the drainage holes. Soil moisture was kept near $70 \%$ field capacity by watering the pots from the top during the experimental period. In each trial, the plants were grown for 18 weeks in the greenhouse without fertilization. For each contamination level, unplanted pots were also prepared for control. At the end of the experiment, all plants were harvested and separated into shoots and roots. Both shoots and roots were washed 
first with tap and then with distilled water, dried and weighed for determination of biomass yields. In addition, soil samples were taken from the rhizosphere (narrow zone surrounding the roots) of each plant and from 5 to $8 \mathrm{~cm}$ depth of unplanted soil to determine soil TPH concentrations. In each soil sample, basal soil microbial respiration was measured as evolved $\mathrm{CO}_{2}$. For this purpose, 3 replicate soil samples of each treatment were incubated for three days at $26^{\circ} \mathrm{C}$ in 250 -ml glass containers closed with rubber stoppers. The evolving $\mathrm{CO}_{2}$ was trapped in $\mathrm{NaOH}$ solution and the excess in alkali was then titrated with $\mathrm{HCl}$. Three glass containers with $\mathrm{NaOH}$ but without soil were also used as controls (Alef, 1995).

\section{Analysis of PAH in Plant Tissues}

Root and shoot tissues of agropyron plants grown in the $\mathrm{C}_{2}$ treatment were analyzed for $\mathrm{PAH}$ in order to determine the possible extent to which hydrocarbons may be taken up by the studied plants from the experimental soil. Root and shoot samples were analyzed separately. They were first rinsed with distilled water several times and then dried for $24 \mathrm{~h}$ at $60^{\circ} \mathrm{C}$. Finally, the samples were Soxhlet-extracted and analyzed using the same procedure as for the soil.

\section{Statistical Analysis}

The experiment was set up in a completely randomized factorial design. Treatment effects on soil TPH concentrations, plant biomass yields, and soil microbial respiration rates were determined by analysis of variance using plant species (in four levels for TPH concentrations and plant biomass yields, in five levels for soil microbial respiration rates) and contamination level (in three levels) as independent factors. The values given represent means of four replicates. Least significant difference (LSD) values were used to establish the significance of differences. The statistical analysis was performed using the statistical program SAS (SAS Institute, 1999).

\section{Results and Discussion}

\section{Soil Properties}

The soil $\mathrm{pH}$ was slightly lower in the petroleum-contaminated soils than in the uncontaminated control soil (Table 1). This decrease in soil $\mathrm{pH}$ may have had beneficial effects on plant growth by increasing the availability of some nutrients in the soil and as a result thereby also may have enhanced the microbial activity in the plant rhizosphere. In contrast, soil electrical conductivity was increased in the contaminated soils, which could have inhibited plant growth and microbial activity in the soil. In similar studies, Dibble and Bartha (1979) observed an optimal $\mathrm{pH}$ of 7.8 for the mineralization of petroleum compounds in soil. Marin et al. (2005) reported a suitable pH range of 7.5-7.6. Ward and Brock (1978) found a reduction in soil microbial metabolic rates by increasing the salinity of petroleum-contaminated soil.

The high concentrations of nitrogen $(\mathrm{N})$, phosphorus $(\mathrm{P})$, and potassium $(\mathrm{K})$ in the contaminated soils can also be considered as positive factors for the plant growth. These nutrients were not added to the soil. In contrast, the high concentrations of $\mathrm{Mn}, \mathrm{Cu}$, and $\mathrm{Cd}$ found in the contaminated soils (Table 1) may have been limiting factors for the plant growth. On the other hand, the accumulation of such metals in soil does not necessarily have 
Table 1

Physico-chemical properties and TPH concentration of the experimental soils $\left(\mathrm{C}_{0}, \mathrm{C}_{1}\right.$, and $\mathrm{C}_{2}$ ) and the oily waste landfill soil used to produce the soils for the treatments $\mathrm{C}_{1}$ and $\mathrm{C}_{2}$

\begin{tabular}{|c|c|c|c|c|}
\hline Characteristic & $\mathrm{C}_{0}$ & $\mathrm{C}_{1}$ & $\mathrm{C}_{2}$ & $\begin{array}{l}\text { Oily waste } \\
\text { landfill soil }\end{array}$ \\
\hline Clay (\%) & 26 & 23 & 20 & 22 \\
\hline $\mathrm{pH}$ & 7.8 & 7.7 & 7.1 & 6.9 \\
\hline $\mathrm{ECe}\left(\mathrm{dS} \mathrm{m} \mathrm{m}^{-1}\right)$ & 7.4 & 7.8 & 8.1 & 9.8 \\
\hline Organic matter (\%) & 1 & 4.7 & 7.5 & 10.2 \\
\hline Total N (\%) & 0.1 & 0.6 & 0.9 & 1.2 \\
\hline $\mathrm{CaCO}_{3}$, equivalent $(\%)$ & 30 & 24 & 21 & 25 \\
\hline Available-P $\left(\mathrm{mg} \mathrm{kg}^{-1}\right)$ & 45 & 74 & 124 & 150 \\
\hline Available-K (mg kg-1) & 121 & 125 & 128 & 145 \\
\hline DTPA-Mn $\left(\mathrm{mg} \mathrm{kg}^{-1}\right)$ & 18 & 29 & 35 & 39 \\
\hline DTPA-Zn $\left(\mathrm{mg} \mathrm{kg}^{-1}\right)$ & 19 & 15 & 12 & 12 \\
\hline DTPA-Cu $\left(\mathrm{mg} \mathrm{kg}^{-1}\right)$ & 5 & 43 & 63 & 89 \\
\hline DTPA-Fe $\left(\mathrm{mg} \mathrm{kg}^{-1}\right)$ & 15 & 31 & 45 & 62 \\
\hline DTPA-Ni (mg kg-1) & 0.1 & 0.8 & 1.3 & 2.8 \\
\hline DTPA-Cd ( $\left.\mathrm{mg} \mathrm{kg}^{-1}\right)$ & $<0.005$ & 2.1 & 4.6 & 6.3 \\
\hline TPHs (mg kg$\left.{ }^{-1}\right)$ & $<50$ & 40360 & 69760 & 102580 \\
\hline
\end{tabular}

a negative influence on plant development and microbial hydrocarbon degradation (Moreno et al., 2003). Furthermore, the high concentration of calcium carbonate in the petroleumcontaminated calcareous soil may have contributed to the adsorption of nutrients as well as hydrocarbon compounds and thus less bioavailability for TPH-degrading microorganisms (Riser-Roberts, 1998).

Toxicity of the petroleum hydrocarbons present in the contaminated soils was the main factor expected to adversely impact plant establishment and growth in the $\mathrm{C}_{1}$ and $\mathrm{C}_{2}$ treatments. The GC analysis of the untreated contaminated soil shows that the contaminating petroleum consisted to a large extent of an unresolved complex mixture (UCM), but also of substantial amounts of low molecular-weight hydrocarbons (Figure 1). The light fractions of soil petroleum hydrocarbons, in particular light aromatic hydrocarbons, are generally more phytotoxic than the heavy fractions (Chaineau et al., 1997). Also, Salanitro et al. (1997) reported that less volatile hydrocarbons such as heavy and medium crude oil or oily waste organics in soil had less phytotoxic effects on plant growth than low molecular-weight hydrocarbons.

\section{Plant Biomass}

The effects of the petroleum contaminants on root and shoot dry matter yield of the studied plants are shown in Figures 2 and 3, respectively. The dry matter yield of all investigated plants significantly $(P<0.05)$ decreased with increasing soil TPH concentration. For instance, a 53, 41, and 58\% decrease was found in the root dry matter yield of safflower, agropyron, and tall fescue, respectively, in the $\mathrm{C}_{1}$ treatment as compared to the $\mathrm{C}_{0}$ treatment, while no significant difference was observed in the root dry mass of sunflower between the $\mathrm{C}_{1}$ and $\mathrm{C}_{0}$ treatments. In the $\mathrm{C}_{2}$ treatment all safflower plants had died prior to harvest and 


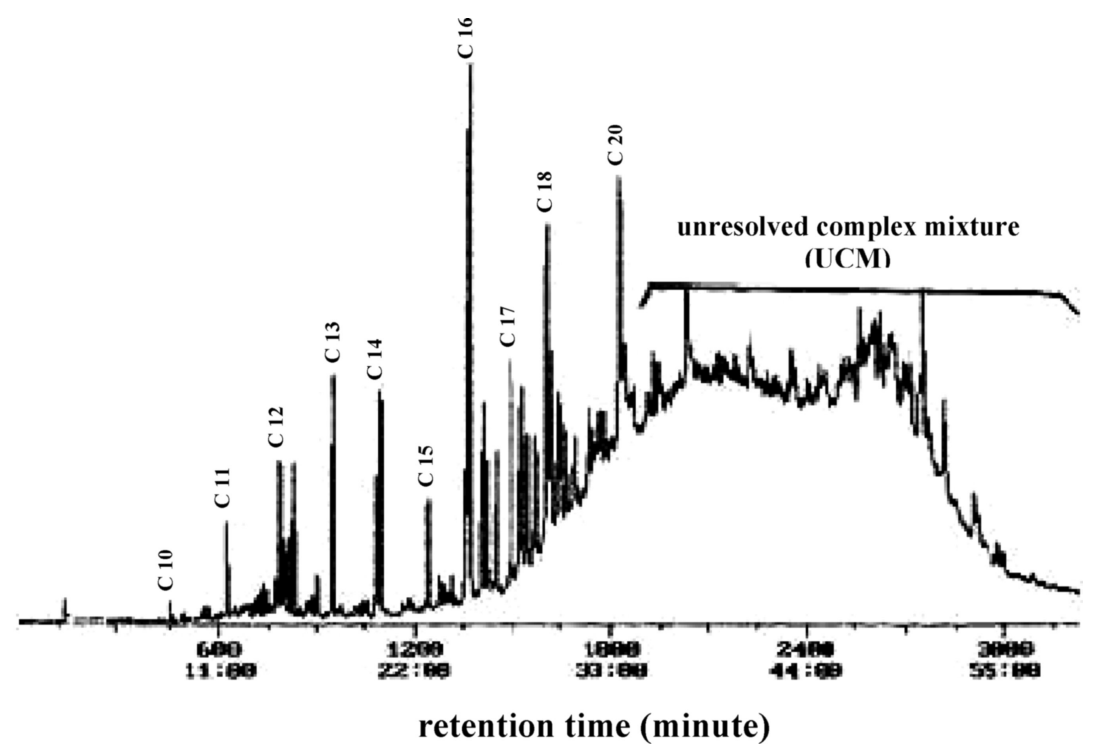

Figure 1. Gas-chromatogram of the petroleum hydrocarbons extracted from the oily waste landfill soil used to produce the experimental soils for treatments $\mathrm{C}_{1}$ and $\mathrm{C}_{2}$.

the root dry matter yield of the other three plant species was decreased by 43,63 , and $69 \%$ in sunflower, agropyron, and tall fescue, respectively (Figure 2). The shoot dry matter yield of sunflower, tall fescue, and agropyron was decreased by 82,80 , and $60 \%$, respectively, in the $\mathrm{C}_{2}$ treatment as compared to the $\mathrm{C}_{0}$ treatment (Figure 3). Differences between the
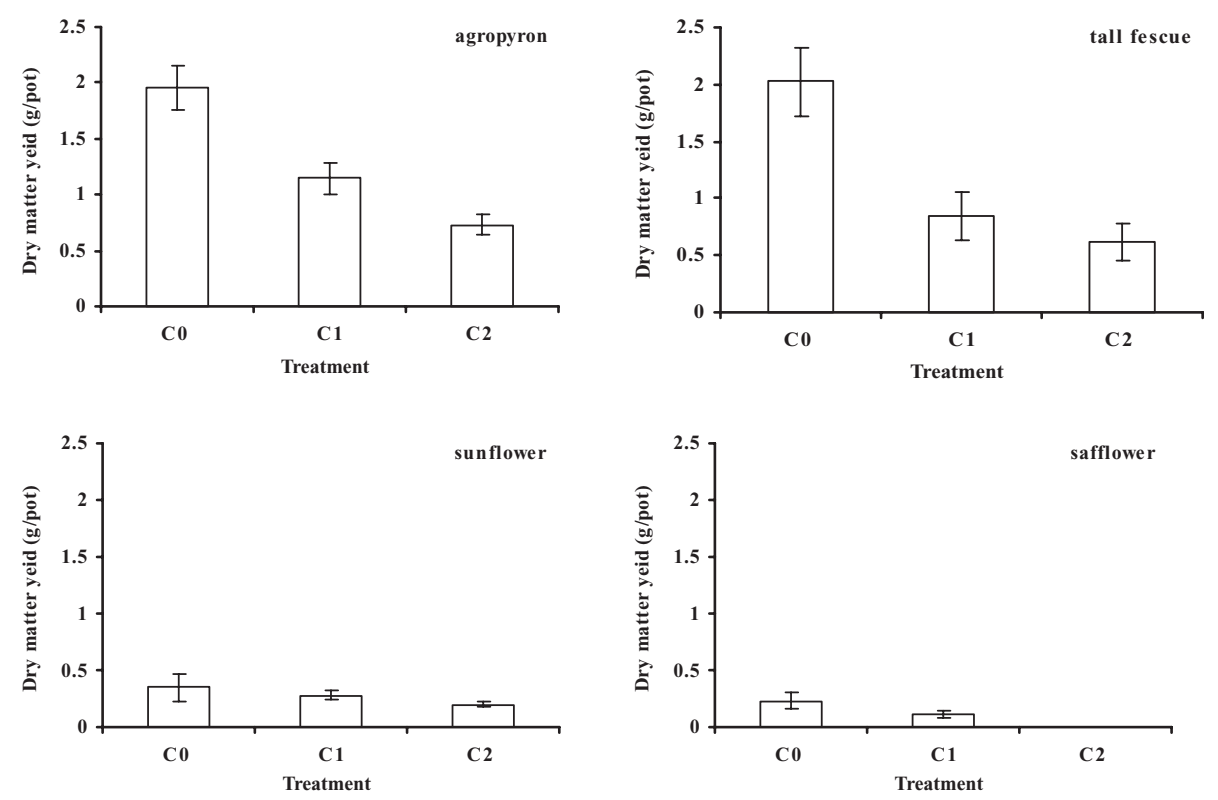

Figure 2. Root dry matter yields produced by agropyron, tall fescue, sunflower, and safflower at soil TPH concentrations of $<50 \mathrm{mg} \mathrm{kg}^{-1}\left(\mathrm{C}_{0}\right), 40360 \mathrm{mg} \mathrm{kg}^{-1}\left(\mathrm{C}_{1}\right)$, and $69760 \mathrm{mg} \mathrm{kg}^{-1}\left(\mathrm{C}_{2}\right)$. 

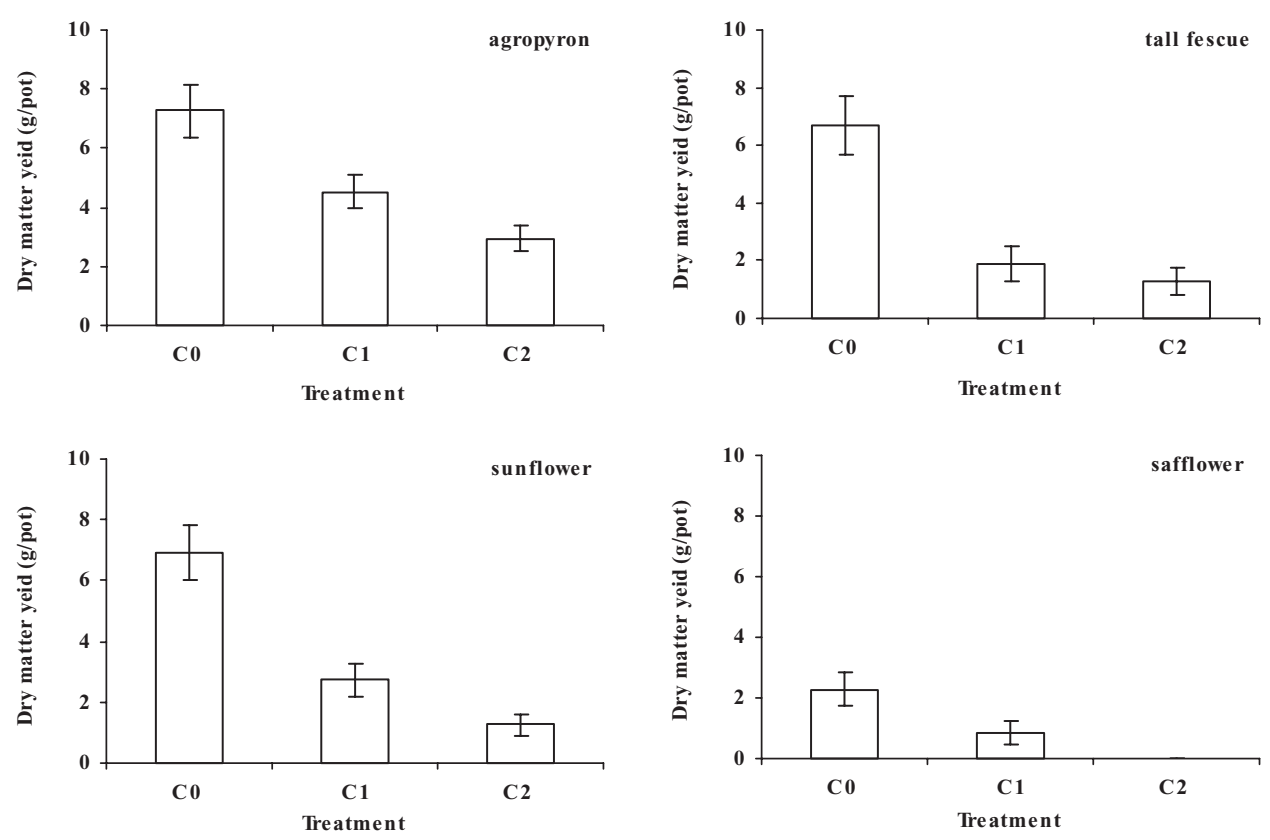

Figure 3. Shoot dry matter yields produced by agropyron, tall fescue, sunflower, and safflower at soil TPH concentrations of $<50 \mathrm{mg} \mathrm{kg}^{-1}\left(\mathrm{C}_{0}\right), 40360 \mathrm{mg} \mathrm{kg}^{-1}\left(\mathrm{C}_{1}\right)$, and $69760 \mathrm{mg} \mathrm{kg}^{-1}\left(\mathrm{C}_{2}\right)$.

$\mathrm{C}_{1}$ and $\mathrm{C}_{2}$ treatments in root and shoot dry matter yield were significant for agropyron and sunflower, but not for tall fescue (Figures 2 and 3).

While the safflower seeds had successfully germinated and developed in the $\mathrm{C}_{2}$ treatment of the previous study (Besalatpour et al., 2008), the safflower seedlings grew poorly and died within 10 to 11 weeks in the current study, although the soil and the contamination level was the same in these treatments of the two studies. It seems that the longer exposure to the petroleum contaminants in the phytoremediation experiment here resulted in more severe toxic effects on the safflower seedlings than in the previous study. In a similar study, Merkl et al. (2005) observed that some of their studied plants died within 6 to 8 weeks in a petroleum-contaminated soil, although in a previous experiment those plant species showed tolerance to the oil contaminations. They concluded that longer exposure time, different shapes of containers, and less fertilization were the main reasons for the stronger toxicity effects in their second experiment.

In similar studies, Chaineau et al. (1997) observed that the inhibition of plant growth increased with increasing soil contamination by hydrocarbons, but not in proportion to the TPH concentration. They reported more than $80 \%$ reduction in the biomass of wheat and bean at a soil hydrocarbon concentration of $0.3 \%$ and less than $30 \%$ reduction in maize at $1.2 \%$. Merkl et al. (2005) found that the shoot and root dry matter production of various grasses significantly decreased in petroleum-contaminated soil. Phytotoxic effects of hydrocarbons in soils were also described by Palmroth et al. (2002). In addition to the inherent phytotoxicity of hydrocarbons, inhibition of plant growth on petroleum-contaminated soil may also result from reduced water and nutrient availability due to hydrophobicity effects (Kechavarzi et al., 2007; Chaineau et al., 1997). 


\section{Soil Microbial Respiration}

In contrast to tall fescue, the presence of sunflower, safflower, and agropyron had no significant $(P<0.05)$ influence on the soil microbial respiration rate in the $\mathrm{C}_{0}$ treatment, indicating that the latter plant species did not substantially affect soil microbial activities in this treatment (Figure 4). In the rhizosphere soil of tall fescue the evolution of $\mathrm{CO}_{2}$ from the soil was $19 \%$ higher than from the unplanted control soil. In the $\mathrm{C}_{1}$ treatment, the soil respiration rate was 77 and $80 \%$ higher in the rhizosphere soil of agropyron and tall fescue, respectively, than in the unplanted control soil, whereas safflower had no significant effect. Sunflower slightly stimulated rhizosphere respiration in the $\mathrm{C}_{1}$ treatment $(12 \%)$, but had no effect on soil respiration rate in the $\mathrm{C}_{2}$ treatment. In the $\mathrm{C}_{2}$ treatment, the highest respiration rate was measured in the rhizosphere soil of agropyron, where the respiration rate was $71 \%$ higher than in the unplanted control soil (Figure 4). The $\mathrm{CO}_{2}$ evolution in the rhizosphere soil of tall fescue was $58 \%$ higher than in the unplanted soil of the $\mathrm{C}_{2}$ treatment. These results correspond well to the better establishment and subsequent root and shoot growth of agropyron as compared to the other plant species in the contaminated soils (Figures 2 and 3 ). Root exudates, including amino acids, organic acids, carbohydrates, growth factors, and soluble proteins, can greatly intensify the microbial activity in the rhizosphere of plants compared to the bulk soil (Miya and Firestone, 2001). Our results agree well with those of other authors: Lie et al. (2002) found that the microbial population densities and respiration rates were higher in the rhizosphere soil of grasses than in unplanted soils. Siddiqui and Adams (2001) reported that the $\mathrm{CO}_{2}$ evolution in the rhizosphere of perennial ryegrass increased after a lag phase of 6 days, when $500 \mathrm{mg} / \mathrm{g}$ diesel hydrocarbons were added to the
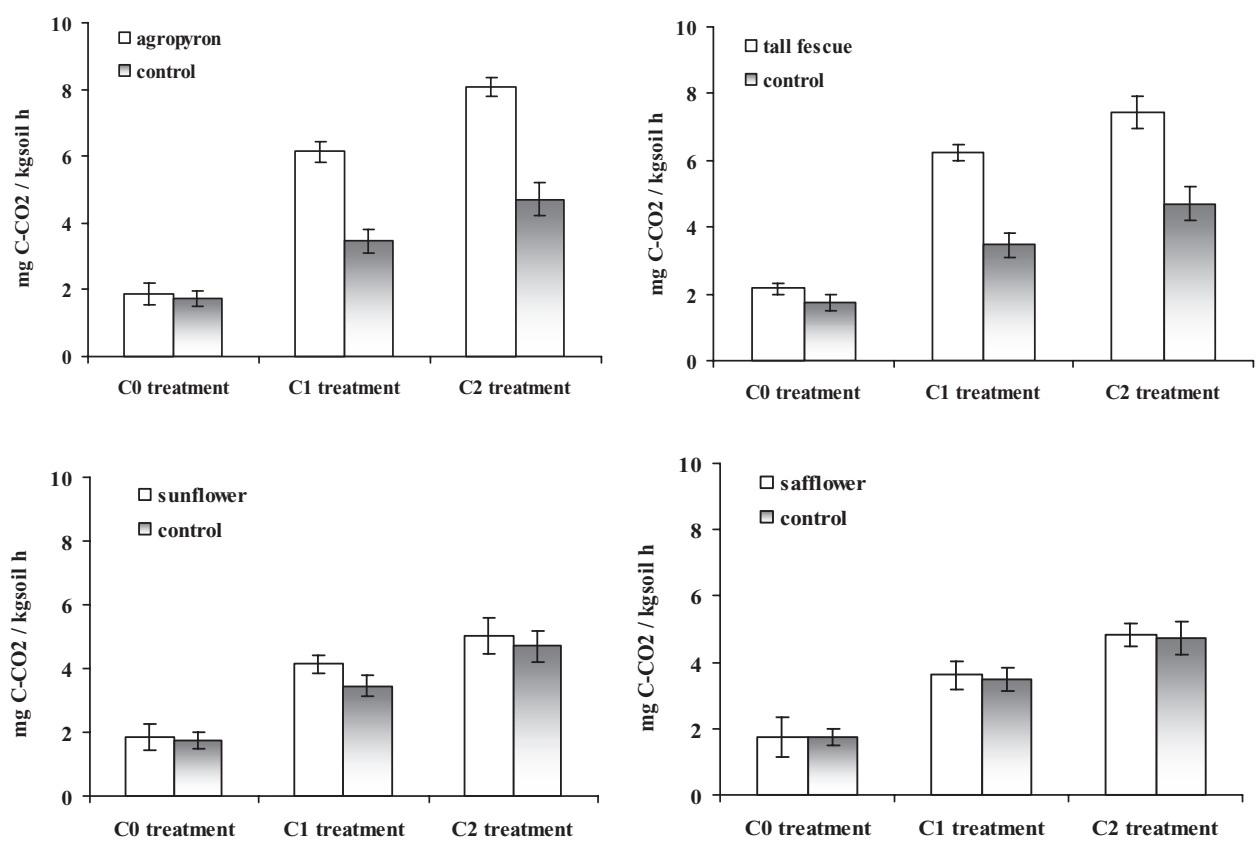

Figure 4. Soil respiration (evolved $\mathrm{CO}_{2}$ ) in the rhizosphere soil of agropyron, tall fescue, sunflower, and safflower and in unplanted control soil at soil TPH concentrations of $<50 \mathrm{mg} \mathrm{kg}^{-1}\left(\mathrm{C}_{0}\right), 40360 \mathrm{mg}$ $\mathrm{kg}^{-1}\left(\mathrm{C}_{1}\right)$, and $69760 \mathrm{mg} \mathrm{kg}^{-1}\left(\mathrm{C}_{2}\right)$. 
Table 2

Analysis of variance of TPH decline in the rhizosphere soil of plant species (agropyron, tall fescue, and sunflower) in the soil TPH contamination levels $\left(\mathrm{C}_{1}\right.$ and $\left.\mathrm{C}_{2}\right)$

\begin{tabular}{lcc}
\hline Source of variations & Degrees of freedom (df) & Mean Squares (MS) \\
\hline Plant & 2 & $7.64^{* *}$ \\
Contamination level & 1 & $16.82^{* *}$ \\
Plant $\times$ Contamination level & 2 & $1.30^{\text {ns }}$ \\
Error & 12 & 0.37 \\
\hline
\end{tabular}

"ns"Indicates no significant differences, ${ }^{* *}$ Significant differences at $P<0.01$.

soil. Gunther et al. (1996) found that microbial respiration rates in soil polluted with PAHs and aliphatic hydrocarbons were higher in the presence of ryegrass than in plant-free soil.

\section{Elimination of Petroleum Hydrocarbons}

The TPH concentrations were measured in the rhizosphere soil of agropyron, tall fescue, and sunflower but not in that of safflower, because safflower seedlings did not survive until the end of the experiment in the $\mathrm{C}_{2}$ treatment and also did not develop well in the $\mathrm{C}_{1}$ treatment (Figures 2 and 3). Furthermore, the respiration rate did not differ significantly between the rhizosphere soil of safflower and the unplanted soil at any of the three contamination levels (Figure 4), indicating that there was no substantial phytostimulation effect.

Analysis of variance showed that the factors plant species (agropyron, tall fescue, and sunflower) and contamination level $\left(\mathrm{C}_{1}\right.$ and $\left.\mathrm{C}_{2}\right)$ had significant $(P<0.01)$ effects on the elimination of petroleum hydrocarbons from soil (Table 2 ). There were significant differences in TPH reduction between agropyron, tall fescue, and unplanted soil in both treatments with contamination $\left(\mathrm{C}_{1}\right.$ and $\left.\mathrm{C}_{2}\right)$, while the presence of sunflowers had no significant effect on the reduction in TPH (Figure 5). These results are in good agreement with the treatment effects on soil respiration (Figure 4) and plant biomass production (Figures 2 and 3).

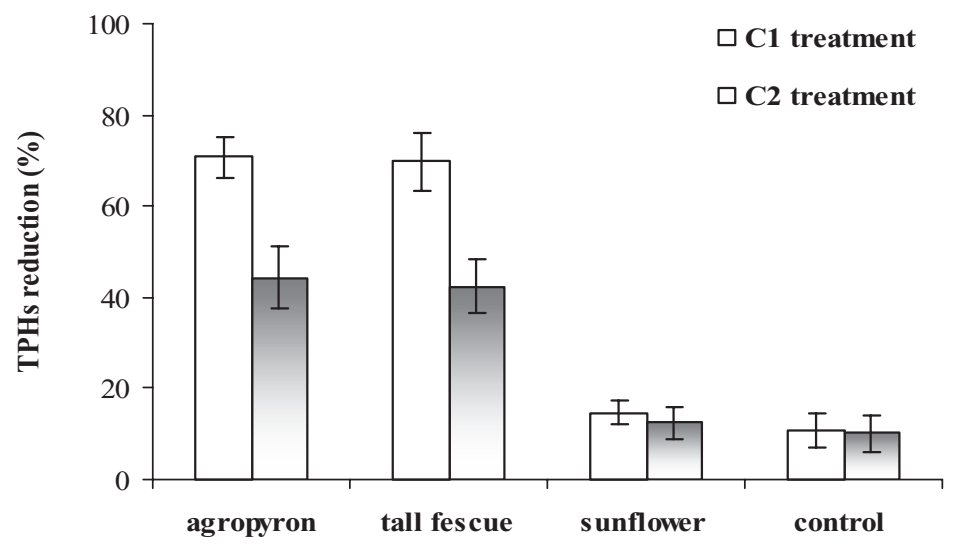

Figure 5. TPH reduction (\%) in the rhizosphere soil of agropyron, tall fescue, and sunflower at initial soil TPH concentrations of $40360 \mathrm{mg} \mathrm{kg}^{-1}\left(\mathrm{C}_{1}\right)$, and $69760 \mathrm{mg} \mathrm{kg}^{-1}\left(\mathrm{C}_{2}\right)$ after 18 weeks of plant growth. 
Agropyron and tall fescue decreased rhizosphere soil TPH concentrations by more than 71 and $69 \%$, respectively, in the $\mathrm{C}_{1}$ treatment and still eliminated about 45 and $42 \%$, respectively, of the total amount of petroleum hydrocarbons in the $\mathrm{C}_{2}$ treatment. Sunflower had no significant $(P<0.05)$ remediation effect (Figure 5). A reason why agropyron and tall fescue provided better conditions for the degradation of petroleum hydrocarbons than sunflower may have been that the more fibrous root systems of the two grasses provided a much more extensive surface area for microbial colonization (cf. Adam and Duncan, 2002). In any case, the lack of a significant phytostimulation effect by the sunflower roots on hydrocarbon elimination is consistent with the negligibly small effects of this plant on soil respiration (Figure 4) and the small biomass production as compared to the two grasses (Figures 2 and 3).

In a similar study, $\mathrm{Xu}$ et al. (2006) found that in soil planted with maize the concentrations of phenanthrene and pyrene were reduced by 92 and $88 \%$, respectively, after 60 days. While Bermuda grass (Cynodon dactylon L.) and tall fescue had no significant effect on soil TPH concentrations in the first 6 months of an experiment performed by Hutchinson et al. (2001), TPH degradation was significantly enhanced in the presence of the two plants after one year. Bermuda grass reduced TPH concentrations in average by $68 \%$ and tall fescue by $62 \%$. Merkl et al. (2005) tested three legumes and three grasses for their ability to stimulate microbial hydrocarbon degradation in a soil with $5 \%(w / w)$ heavy crude oil. They found that the TPH concentration of the planted soil was always lower than that of the unplanted soil and recommended Brachiaria brizantha L. for phytoremediation of petroleum-contaminated tropical soils.

\section{PAH Uptake by Agropyron}

The phytoaccumulation of hydrocarbons can pose a risk to human and animal nutrition (Palmroth et al., 2002). Therefore, we studied the PAH concentrations in the root and shoot tissues of agropyron plants grown in the $\mathrm{C}_{2}$ treatment to evaluate if the plants could accumulate potentially toxic hydrocarbon compounds from the petroleum-contaminated soil. The analyses showed that some PAH compounds were present in root and shoot samples in detectable concentrations (Table 3). The concentrations of these compounds were generally higher in the belowground tissues of agropyron than that in the aboveground tissues. Perylene was found in the highest concentration of all PAH compounds found in

Table 3

$\mathrm{PAH}-$ concentrations in the root and shoot tissues of agropyron in the $\mathrm{C}_{2}$ treatment

\begin{tabular}{lcc}
\hline PAHs & $\begin{array}{c}\mu \mathrm{g} \mathrm{kg}^{-1} \text { root } \\
\text { dry weight }\end{array}$ & $\begin{array}{c}\mu \mathrm{g} \mathrm{kg}^{-1} \text { shoot } \\
\text { dry weight }\end{array}$ \\
\hline 1-Methylnaphtalen & 5.5 & 1.3 \\
Acenaphthylene & 41.4 & 11.1 \\
Acenaphthene & 3.9 & 1.1 \\
2-Methylphenenthrene & 7.8 & 5.2 \\
3,6-Dimethylephenantrene & 43.2 & 34.3 \\
Benzo(a)anthracene & 13.9 & 11.6 \\
Benzo(a)pyrene & 49.8 & 29.9 \\
Perylene & 51.6 & 29.5 \\
\hline
\end{tabular}


the analyzed agropyron plants (Table 3). Several other studies also demonstrated that PAH compounds can be taken up by plants grown on contaminated soils (Ryan et al., 1988; Radwan et al., 2000; Samsoe-Petersen et al., 2002; Wennrich et al., 2002; Gao and Zhu, 2004; Watts et al., 2006). Watts et al. (2006), for instance, reported that Spartina alterniflora plants grown on PAH contaminated sediments contained measurable amounts of PAHs in their roots and leaves. Radwan et al. (2000) found accumulation of long-chain hydrocarbons in broad bean (Vicia faba) grown on petroleum-contaminated soil. Ryan et al. (1988) studied PAH uptake by plants in dependence of plant species and concentrations in soil and found a large variability. Gao and Zhu (2004) reported plant uptake of phenanthrene and pyrene from contaminated soils.

\section{Conclusion}

The results of this study show that phytoremediation has great potential for the treatment of petroleum-contaminated soil, provided that the plant species used for this purpose are chosen carefully. Safflower and sunflower were not found to be effective phytoremediation plants in the case of the experimental soil because they suffered too much from phytotoxicity effects and did not significantly enhance TPH reduction. In contrast the two grasses, agropyron and tall fescue, performed well in stimulating the elimination of the contaminating petroleum hydrocarbons from the experimental soil. The fact that these plants grew in the petroleum-contaminated soils without addition of nutrients is also a further advantage as cost would be reduced without fertilizer amendments.

\section{References}

Adam, G., and Duncan, H. 2002. Influence of diesel fuel on seed germination. J. Environ. Pollut. 120, 363-370.

Alef, K. 1995. Soil respiration. In: Methods in Applied Soil Microbiology and Biochemistry, chapter 5, pp. 214-216 (Alef, K. and Nannipieri, P., eds.), Harcourt Brace, London.

Alkorta, I., and Garbisu, C. 2001. Phytoremediation of organic contaminants in soils. Bioresource Technol. 79, 273-276.

Aprill, W., and Sims, R.C. 1990. Evaluation of the use of prairie grasses for stimulating polycyclic aromatic hydrocarbon treatment in soil. Chemosphere. 20, 253-265.

Besalatpour, A., Khoshgoftarmanesh, A.H., Hajabbasi, M.A., and Afyuni, M. 2008. Germination and growth of selected plants in a petroleum-contaminated calcareous soil. Soil Sediment Contamin. 17(6), 665-676.

Bremner, J.M., and Mulvaney, C.S. 1982. Nitrogen-total. In: Methods of Soil Analysis, Part 2, pp. 595-624 (Page, A.L., ed.), American Society of Agronomy, Madison, Wis.

Chaineau, C.H., Morel, J.L., and Oudot, J. 1997. Phytotoxicity and plant uptake of fuel oil hydrocarbons. Environ. Qual. 26, 1478-1483.

Chaineau, C.H., Morel, J.L., and Oudot, J. 2000. Biodegradation of fuel oil hydrocarbons in the rhizosphere of maize. Environ. Qual. 29, 569-578.

Christopher, S.H., Marsden, P.J., and Sharleff, A.S. 1988. Evaluation of methods 3540 (Soxhlet) and 3550 (Sonication) for evaluation of appendix IX analyses from solid samples. S-CUBED, Report for EPA contract 68-03-33-75, work assignment no. 03, document no. SSS-R-88-9436.

Dibble, J.T., and Bartha, R. 1979. Effect of environmental parameters on the biodegradation of oil sludge. Appl. Environ. Microbiol. 37, 729-739.

Gao, Y., and Zhu, L. 2004. Plant uptake, accumulation, and translocation of phenanthrene and pyrene in soils. Chemosphere. 55, 1169-1178.

Gunther, T.H., Dornberger, U., and Fritsche, W. 1996. Effect of ryegrass on biodegradation of hydrocarbons in soil. Chemosphere. 33, 203-215. 
Huang, X.D, Alawi, Y.E., Gursska, J., Glick, B.R., and Greenberg, B.M. 2005. A multi process phytoremediation system for decontamination of persistent total petroleum hydrocarbons (TPHs) from soils. Microchem. 81, 139-147.

Huang, X.D., Alawi, Y.E., Penrose, D.M., Glick, B.R., and Greenberg, B.M. 2004. A multi process phytoremediation system for removal of polycyclic aromatic hydrocarbons from contaminated soil. J. Environ. Pollut. 130, 465-476.

Hutchinson, S.L., Banks, M.K., and Schwab, A.P. 2001. Bioremediation and Biodegradation. Phytoremediation of aged petroleum sludge: Effect of inorganic fertilizer. Environ. Qual. 30, 395403.

Joner, E.J., and Leyval, C. 2001. Influence of arbuscular mycorrhiza on clover and ryegrass grown together in a soil spiked with polycyclic aromatic hydrocarbons. Mycorrhiza. 10, 155-159.

Kechavarzi, C., Karin, P., Leeds, H., Laurie, R., and Stig, L. 2007. Root establishment of perennial ryegrass (L. perenne) in diesel-contaminated subsurface soil layers. J. Environ. Pollut. 145, 68-74.

Leyval, C., and Binet, P. 1998. Effect of polycyclic aromatic hydrocarbons in soil on arbuscular mycorrhizal plants. Environ. Qual. 27(2), 402-407.

Lie, C.H., Ma, B.L., and Zhang, T.O. 2002. Soil bulk density effects on soil microbial population and enzyme activities during the growth of maize (Zea Mays) planted in large pots under field exposure. Plant. Sci. 82, 147-154.

Lindsay, W.L., and Norvell, W.A. 1978. Development of a DTPA soil test for zinc, iron, manganese, and copper. Am. Soil Sci. Soc. J. 42, 421-428.

Liste, H.H., and Felgentreu, D. 2005. Crop growth culturable bacteria and degradation of petrol hydrocarbons (PHCs) in a long term contaminated field soil. Appl. Soil Technol. 31, 43-52.

Marin, J.A., Hernandez, T., and Garcia, C. 2005. Bioremediation of oil refinery sludge by landfarming in semiarid conditions: Influence on soil microbial activity. Environ. Res. 98, 185-195.

McNicoll, D.M., and Baweja, A.S. 1995. Bioremediation of petroleum-contaminated soils: An innovative, environmentally friendly technology. Technical Report, The National Contaminated Sites Remediation Program, Cat. no. EN40-491/1995. Environment Canada, Ottawa, ON.

Merkl, N., Karft, R.S., and Infant, C. 2005. Assessment of tropical grasses and legumes for phytoremediation of petroleum-contaminated soils. Water Air Soil Pollut. 165, 195-209.

Miya, R.K., and Firestone, M.K. 2001. Enhanced phenanthrene biodegradation in soil by slender oat root exudates and root debris. Environ. Qual. 30, 1911-1918.

Mol, J.J. W. 1999. An analysis of the remediation of oil-contaminated refinery sites. Environ. Manage. Health. 10(1), 37-40.

Moreno, J.L., Garcia, C., and Hernandez, T. 2003. Toxic effect of cadmium and nickel on soil enzymes and the influence of adding sewage sludge. Eur. J. Soil Sci. 54, 377-386.

Nedunuri, K.V., Govindaraju, R.S., Banks, M.K., Schwab, A.P., and Chen, Z. 2000. Evaluation of phytoremediation for field scale degradation of total petroleum hydrocarbons. Environ. Eng. 126(6), 483-490.

Nelson, D.W., and Sommers, L.E. 1982. Total carbon, organic carbon, and organic matter. In: Methods of Soil Analysis, Part 2, pp. 539-579 (Page, A.L., ed.), American Society of Agronomy, Madison, Wis.

Newman, L.A., and Reynolds, C.M. 2004. Phytodegradation of organic compounds. Curr. Opin. Biotech. 15, 225-230.

Nicolotti, G., and Eglis, S. 1998. Soil contamination by crude oil: Impact on the mycorrhizosphere and on the vegetation potential of forest trees. J. Environ. Pollut. 99, 37-43.

Olsen, S.R., and Sommers, L.E. 1982. Phosphorus. In: Methods of Soil Analysis, Part 2, pp. 403-431 (Page, A.L., ed.), American Society of Agronomy, Madison, Wis.

Palmroth, M.R., Pichtel, T.J., and Puhakka, J.A. 2002. Phytoremediation of sub arctic soil contaminated with diesel fuel. Bioresource Technol. 84, 221-228.

Radwan, S.S., Al-Awadhi, H., and El-Nemr, I.M. 2000. Cropping as a phytoremediation practice for oily desert soil with reference to crop safety as food. Int. J. Phytoremediat. 2(4), 383-396. 
Rhoades, J.D. 1996. Salinity: Electrical conductivity and total dissolved solids. In: Methods of Soil Analysis, Part 2, pp. 417-435 (Page, A.L., ed.), American Society of Agronomy, Madison, Wis.

Riser-Roberts, E. 1998. Remediation of Petroleum Contaminated Soils: Biological, Physical, and Chemical Processes. CRC Press, Boca Raton, FL.

Rock, S. 1997. Phytoremediation. In: Standard Handbook of Hazardous Waste Treatment and Disposal, 2nd ed., pp. 93-112 (Freeman, H., ed.), McGraw Hill Inc., New York.

Ryan, J., Bell, R., Davidson, J., and Connor, G. 1988. Plant uptake of non-ionic organic chemicals from soils. Chemosphere. 17, 2299-2323.

Salanitro, J.P., Doran, P.B., Huesemann, M.H. Moore, K.O., Rhodes, I.A., Jackson, L.M., Vipond, T.E., Wetern, M.M., and Wisniewski, H.L. 1997. Crude oil hydrocarbon bioremediation and ecotoxicity assessment. Environ. Sci. Technol. 31, 1769-1776.

Samsoe-Petersen, E.H., Larsen, P.B., and Bruun, P. 2002. Uptake of trace elements and PAHs by fruit and vegetables from contaminated soils. Environ. Sci. Technol. 36, 3057-3063.

SAS Institute. 1999. SAS/STAT User's Guide, release 8.2. SAS Institute, Cary, NC.

Siddiqui, S., and Adams, W.A. 2001. The fate of diesel hydrocarbons in soils and their effect on the germination of Perennial Ryegrass. J. Environ. Pollut. 118, 49-62.

Smith, M.J., Flowers, T.H., Duncan H.J., and Adler, J. 2006. Effects of polycyclic aromatic hydrocarbons on germination and subsequent growth of grasses and legumes in freshly-contaminated soil and soil with aged PAHs residues. J. Environ. Pollut. 141, 519-525.

Thomas, G.W. 1996. Soil pH and soil acidity. In: Methods of Soil Analysis, Part 2, pp. 475-490 (Page, A.L., ed.), American Society of Agronomy, Madison, Wis.

US. EPA. 2000. Introduction to Phytoremediation. US.EPA/600/R-99/107, Washington, DC.

Ward, D.M., and Brock, T.D. 1978. Hydrocarbons biodegradation in hypersaline environments. Appl. Environ. Microbiol. 35, 353-359.

Watts A.W., Ballestero T.P., and Gardner, K.H. 2006. Uptake of polycyclic aromatic hydrocarbons (PAHs) in salt marsh plants Spartina alterniflora grown in contaminated sediments. Chemosphere. 62, 1253-1260.

Wennrich, L., Popp, P., and Zeibig, M. 2002. Polycyclic aromatic hydrocarbon burden in fruit and vegetable species cultivated in allotments in an industrial area. Int. J. Environ. Ana. Chem. 82, 677-690.

Xu, S.Y., Chen, Y.X., Wu, W.X., Wang, K.X., Lin, Q., and Liang, X.Q. 2006. Enhanced dissipation of phenanthrene and pyrene in spiked soils by combined plants cultivation. Sci. Total Environ. 363, 206-215.

Yoon, J., Cao, X., Zhou, Q., and Ma, L.Q. 2006. Accumulation of $\mathrm{Pb}, \mathrm{Cu}$, and $\mathrm{Zn}$ in native plants growing on a contaminated Florida site. Sci. Total Environ. 368, 456-464. 